Jurnal Kesehatan Masyarakat
http://journal.unnes.ac.id/nju/index.php/kemas

\title{
ACCEPTANCE BEHAVIOR OF ELECTRONIC PRESCRIPTION SYSTEM
}

\author{
Rapitos Sidiq
}

Politeknik Kesehatan Kemenkes RI, Aceh, Indonesia

\section{Article Info \\ Article History: \\ Submitted Mei 2017 \\ Accepted November 2017 \\ Published November 2017 \\ Keywords: \\ Behavior; acceptance; \\ prescribing; electronics \\ DOI \\ http://dx.doi.org/10.15294/ \\ kemas.v13i2.9703}

\begin{abstract}
Electronic prescription is one of information systems to support medical services based on computer technology to support clinical decision (Clinical Decision Support, CDS). Studies proved that the use of this system can decrease medication error. One of the hospitals that have applied this system is Meuraxa Hospital. This study aimed to determine the acceptance behavior of electronic prescription information systems. The respondents of this study were 30 doctors at specialist clinic. Data was collected by distributing questionnaires on August 1st-23rd, 2016. Data was processed using SmartPLS 3.0. Results showed that there was a positive effect of effort expectancy factor on behavioral intention and facilitating factors on the use behavior towards receipt of electronic prescription. It is expected that the management of Meuraxa hospital develop an existing electronic prescription system by accommodating the needs of the system users.
\end{abstract}

\section{Introduction}

The use of information technology in health sector, especially in hospitals, offers great potential to improve the quality and efficiency of the service provided, effectiveness of personnel, and reduce organizational costs (Aggelidis, 2008). The existence of information technology should ease the work in an organization including hospitals. However, its existence might raise either acceptance or rejection behavior from its users. Thus, it might generate question of how far is the acceptance of hospital workers toward information technology while doing their works. (Hahn, 2014; Dhavle, 2015). One of the information technology developments in health sector is the application of electronic prescription system known as CPOE which stands for Computerized
Physician Order Entry. CPOE is a medication order recording system from doctors based on computer technology (Eslami, 2007). CPOE is a form of clinical decision support (CDS) system because the information and knowledge submitted by the doctor would be useful to provide the best decision in treating patients (Rimbault, 2013; North, 2014). The implementation of this system in developed countries is one of health service quality indicator (clinics and hospitals), even the CPOE application become one of standard quality of health service. The combination of CPOE and eMAR (electronic medication administration records) become a very important component in electronic medication recording system (Appari, 2012). In Indonesia, the application of this system remains rare. This is caused by

\footnotetext{
Correspondence Address:

Jl. Soekarno Hatta, Tingkeum, Darul Imarah, Lheu Blang, Banda Aceh, Kabupaten Aceh Besar, Aceh 23231 
several obstacles, ranging from connectivity system of inter-unit/inter-department of a hospital to regulation problem (Asyary, 2013). Rumah Sakit Umum Daerah (RSUD) Meuraxa (Meuraxa District Hospital) in Banda Aceh city is one of the hospitals which has been using CPOE in Aceh since 2015. In the application, this system is integrated with sistem informasi manajemen rumah sakit (SIM-RS) or hospital management information system. The purpose of the information system, aside from to reduce medication error, is also to act as a system that give consideration for physicians in prescribing medication as indicated by the diseases. It is expected that the use of electronic prescribing system may reduce adverse drug event (ADE) caused by medication prescription error such as mistake in writing drug's name, determining drug's dosage, and using drug's type. Study revealed that the application of this system might reduce patient's waiting time in pharmacy compared to manual system (Schreiber, 2014). Based on the observation and direct interview we conducted on February 22 2016 in RSUD Meuraxa, the implementation of the system is not so ideal, because data is entered to the system by nurse. On interview, one of the nurse stated that for inpatients, doctor would just prescribe like usual, whereas the task to enter the prescription to the system would be conducted by nurse. This condition presented an additional task for nurse, leading to complaint from some of them. When further inquired, the reason the doctor did not directly enter the data to the system is unclear regulation and lack of firmness from the head of the ward. Through this interview, we revealed that direct prescription entry process to the system applied only for outpatients. This is in accordance to our observation on February 24th, 2016 in one of the specialist polyclinics in which the doctor enter the prescription data after serving the patient.

Interview result between author and a pharmacist on February 13th, 2016 revealed a common problem on electronic prescription system when doctors forgot to enter the prescription that the patient gets no medications. Based on these conditions, the implementation of CPOE failed to achieve the purpose of information system application which is to accelerate drug ordering process and to reduce the number of people needed to participate on the working flow, so as to reduce the delay and error because of miscommunication (Hoonakker, 2012). While applying information technology, especially in the medical field, three main factors play a role, that is: user perception regarding ease of use of the application, complexity, and perception toward the benefit of an IT (Benmessaoud, 2011). UTAUT framework is commonly used by many researchers to estimate acceptance of a technology by users, in order to measure the influence of the technology in its application. UTAUT method puts factors affecting people in using an information system or technology with the following construct: performance expectancy, effort expectancy, social influence, facilitating condition, and actual system usage. A health information system is always affected by three main factors: technical factor, organizational environment, and people behavior toward the information system (Aqil, 2009). Furthermore, evaluation is very important to be carried out to identify the problem and satisfaction of electronic prescription system (Hoonakker, 2010). This study is aimed to understand the factors that influence behavior on accepting electronic prescription information system/computerized physician order entry (CPOE in RSUD Meuraxa Banda Aceh City).

\section{Method}

This was a cross sectional study using sample of 30 specialist doctors in polyclinic of RSUD Meuraxa. Data were collected in August $1^{\text {st }}-23^{\text {rd }}, 2016$ through interview using adopted UTAUT model questionnaire. It is composed of two parts, demographic data and factors that influence behavior on accepting electronic prescription information system which consisted of performance expectancy, effort expectancy, social influence and facilitating conditions. The questionnaire used five (5) points of Liker scale ranging from "strongly disagree" (1) to "strongly agree" (5). This research model is shown in Picture 1. Data analysis used quantitative analysis using PLS software, smartLPS 3.0, conducted in two parts. First is outer model analysis to make sure that measurement tools were proper for measuring 
(valid and reliable), consisted of Convergent Validity. Convergent validity is loading factors value on latent variable with its indicators. The expected value was $>0.6$. Discriminant validity. This value is cross loading factor value used to know whether construct has sufficient discriminant by comparing loading value toward addressed construct must be greater than other construct loading values. Composite reliability. Data having composite reliability $>0.7$ are have higher reliability. Average Variance Extracted (AVE). Expected AVE value is $>0.5$. Cronbach Alpha. Reliability testing is strengthened by Cronbach Alpha. Expected value is $>0.6$ for all constructs. Second is hypothesis testing. Hypothesis testing was conducted by determining its probability value and $\mathrm{t}$-statistic. For probability value, $\mathrm{p}$-value with alpha $5 \%$ is less than 0.05 . T-table value for alpha $5 \%$ is 1.96 . Thus, hypothesis acceptance criteria is when $\mathrm{t}$-statistic $>\mathrm{t}$-table.

\section{Results and Discussion}

Characteristics of respondents from this study such as gender, age, specialization, time duration for using application and working status, are shown in detail on table 1. Based on the table, the respondents was mostly female (70\%) and under 40 years (56.7\%). Out of 30 people from 12 polyclinics, $5(16.7 \%)$ are from the dental clinic. About $90 \%$ of respondents reported having used electronic prescription application for more than 1 year. Furthermore, $83.3 \%$ are working as civil servant.

The next step was to test the outer models in which loading factor values were obtained as follows: all of PE (Performance expectancy) statements had value above 0.6, except for PE4, while for all of EE (Effort expectancy) questions had value above 0.6. Then, SI (Social Influence) statements which have value $>0.6$ were SI1 and SI2. For FC (Facilitating conditions), statements having value above 0.6 were FC 5 and FC 8. And for BI (Behavioral intention), all of the statements have value above 0.6. As stated in the rules, any items having loading factor value below 0.6 must be excluded from the model. Statements which meet the requirements were statements having loading factor value $>6$ to gain several indicator values, mainly for Average Variance

Table 1. Respondents' Distribution Based on Characteristics

\begin{tabular}{llcc}
\hline & Characteristics & Frequency & $\%$ \\
\hline \multirow{2}{*}{ Gender } & Male & 9 & 30.0 \\
\multirow{4}{*}{ Age } & Female & 21 & 70.0 \\
& Less than 40 years old & 13 & 43.3 \\
& $\geq 40$ years old & 17 & 56.7 \\
& Pediatrics & 3 & 10.0 \\
& Surgery & 3 & 10.0 \\
& Pediatrics Surgery & 1 & 3.3 \\
Specialization & Dental & 5 & 16.7 \\
& Dental and Mouth & 1 & 3.3 \\
& Eye & 2 & 6.7 \\
& OG & 1 & 3.3 \\
& Pulmonology & 2 & 6.7 \\
& Internal Medicine & 4 & 13.3 \\
& Psychiatry & 1 & 3.3 \\
Time duration & Medical Rehabilitation & 1 & 3.3 \\
application & Neurology & 2 & 6.7 \\
& 1 years & 3 & 10.0 \\
Working Status & & & \\
& More than 1 years & 27 & 90.0 \\
Sum & & & 83.3 \\
\hline
\end{tabular}

Source : Primary data, 2016 
Extracted (AVE) values where it is shown in table 2.

Table 2. Reliability and Validity of Constructs

\begin{tabular}{lcc}
\hline \multicolumn{1}{c}{ Constructs } & $\begin{array}{c}\text { Cronbach's } \\
\text { Alpha }\end{array}$ & $\begin{array}{c}\text { Composite } \\
\text { Reliability }\end{array}$ \\
\hline $\begin{array}{l}\text { Social influence } \\
\begin{array}{l}\text { Performance } \\
\text { expectancy }\end{array}\end{array}$ & 0.734 & 0.737 \\
$\begin{array}{l}\text { Effort expectancy } \\
\text { Facilitating }\end{array}$ & 0.916 & 0.916 \\
$\begin{array}{l}\text { conditions } \\
\text { Behavior intention }\end{array}$ & 0.857 & 0.858 \\
\hline
\end{tabular}

Source : Primary Data, 2016

Based on the table, it could be extracted that discriminant validity results obtained that root square value of AVE Social influences: 0.585, Performance expectancy: 0.784, Effort expectancy: 0.548 , Facilitating conditions: 0.784 and Behavior intention: 0.674 . AVE values from the following model were above 0.5 , so there was no problem with the convergent validity from the tested model. The final steps, to ensure there was no problem with measurement, was outer model evaluation by testing unidimensionality of the model using Composite reliability indicator and alpha cronbach. For those, cut-off value was 0.7 . The result of reliability composite values and alpha cronbach values could be seen in table 3. Based on table 3, Composite Reliability and Alpha Cronbach values for all constructs had Composite reliability value of $>0,7$ so that it could be concluded that there was no problem of reliability/unidimensionality from the formed model.

Table 3. Composite Reliability Value and Alpha Cronbach

The next step was to conduct hypothesis

\begin{tabular}{lccc}
\hline Constructs & $\begin{array}{c}\text { Cronbach's } \\
\text { Alpha }\end{array}$ & $\begin{array}{c}\text { Composite } \\
\text { Reliability }\end{array}$ & $\begin{array}{c}\text { Average } \\
\text { Variance } \\
\text { Extracted } \\
\text { (AVE) }\end{array}$ \\
\hline $\begin{array}{l}\text { Social } \\
\text { influence }\end{array}$ & 0.734 & 0.737 & 0.585 \\
$\begin{array}{l}\text { Performance } \\
\text { expectancy }\end{array}$ & 0.916 & 0.916 & 0.784 \\
$\begin{array}{l}\text { Effort } \\
\text { expectancy }\end{array}$ & 0.857 & 0.858 & 0.548 \\
$\begin{array}{l}\text { Facilitating } \\
\text { conditions }\end{array}$ & 0.771 & 0.775 & 0.784 \\
$\begin{array}{l}\text { Behavior } \\
\text { intention }\end{array}$ & 0.853 & 0.860 & 0.674 \\
\hline
\end{tabular}

Source : Primary Data, 2016 testingusingstatistic valuewith $5 \%$ alphawhereas $\mathrm{t}$-statistic value used was 1.96 . Thus hypothesis acceptance/rejection criteria was Ha being accepted and Ho being rejected when t-statistic $>$ 1.96. To rejecting/accepting hypothesis using probability, Ha would be accepted if $\mathrm{p}<0.05$. The result of hypothesis testing is shown in Table 4. Based on the table, we concluded that: (1) Behavior intention did not positively affect behavioral intention in accepting electronic prescribing system/computerized physician order entry (CPOE) in RSUD Meuraxa, Banda Aceh City, p-value: 0.648 ( $p>0.05)$, (2) effort expectancy had positive influence toward behavioral intention in accepting electronic prescribing system/computerized physician order entry (CPOE) in RSUD Meuraxa, Banda Aceh City, p-value: $0.000(p<0.05),(3)$ facilitating conditions positively affected use behavior in accepting electronic prescribing system/computerized physician order entry (CPOE) in RSUD Meuraxa, Banda Aceh City, p-value: $0.024 \quad(p<0.05), \quad(4)$ performance expectancy did not positively affect behavioral intention in accepting electronic prescribing system/computerized physician order entry (CPOE) in RSUD Meuraxa, Banda Aceh City, p-value: 0.648 ( $p>0,05),(5)$ social influence did not positively affect behavioral intention in accepting electronic prescribing system/ computerized physician order entry (CPOE) in RSUD Meuraxa, Banda Aceh City, p-value: $0.773(\mathrm{p}>0,05)$.

Regarding acceptance of electronic prescribing system/computerized physician order entry (CPOE) in RSUD Meuraxa, Banda Aceh city, our study found that effort expectancy had positive influence toward behavioral intention whereas facilitating conditions had positive influence toward use behavior. Effort expectancy was defined as level of convenience in using the system. It means that respondents use electronic prescribing system because it is easy to use. Vekantes (2009), said that one of factors affecting technology acceptance is convenience in use (ease of use). Perceived ease of use is defined as the extent to which a person believes that using a technology will be effortless (Tsai, 2014). It means that someone would use a technology, when they believe that the information system is easy to use, and 
Table 4. Hypothesis Test Results

\begin{tabular}{lcc}
\hline \multicolumn{1}{c}{ Constructs } & Statistic $\mathrm{t}$ value & P- Value \\
\hline Behavior Intention $=>$ Use Behavior & 0.400 & 0.692 \\
Effort Expectancy $=>$ behavioral intention & 6.295 & 0.000 \\
Facilitating Conditions $=>$ use behavior & 2.376 & 0.024 \\
Performance expectancy => behavioral intention & 0.461 & 0.648 \\
Social influence $=>$ behavioral intention & 0.291 & 0.773 \\
\hline
\end{tabular}

Source : Primary Data, 2016

vice versa, they would not use it if they believe it is difficult to use. User confidence towards electronic prescribing system or $\mathrm{CPOE}$ becomes the factor behind the success of application of this system, in addition to training factors and willingness to change (Kruse, 2015). Study conducted by Hoonaker (2010), also managed to detect satisfaction among doctors and nurses towards electronic prescribing system/CPOE where 158 respondents $(89.2 \%)$ reported being satisfied due to its ease of use.

The next hypothesis was where there was a positive influence between Facilitating Conditions and use behavior. Facilitating conditions is objective conditions supporting information system usage that it eases prescribing medication to patients. Facilitating conditions could also be defined as the extent of which a person to believe that organization infrastructures and existing techniques could support system use. Facilitating conditions in this situation could be in the form of computer connectivity, IT supports, including managerial policies to implement this prescribing system. The success of implementation of health information technology such as this $\mathrm{CPOE}$ verily depends on the agreement between users and IT facilities (Holden, 2010). RSUD Meuraxa took courage to invest with great expenses to provide those facilities, such as computer connectivity, electricity, and also IT staffs, although massive investment by no mean guarantee that such information system managerial would work well but still depends on the ability to choose the strategies applied by managerial staffs (Indrajit, 2009). A study conducted by Phichitchaisopa (2013), found that there are significant factors affecting health technology acceptance behavior such as performance expectancy, effort expectancy and facilitating conditions. It differs from our current study in which we find no relation between performance expectancy factors and health technology acceptance behavior. In that case, it seems there is a phenomenon in which hospital information system acceptance behavior is affected by many other factors. Those factors are different among hospitals. Electronic prescription system has commenced in RSUD Meuraxa, although not all doctors did the data entry, with the help from the nurses. In essence, CPOE is an electronic application used by doctors to provide drugs prescription service (Poon, 2004). This CPOE data entry phenomenon occurred not only in RSUD Meuraxa, but also in other hospital as evidenced by particular study by Hoonakker (2010), involving 120 nurses and 50 doctors about their satisfaction towards CPOE. The study showed that nurse involvement in this system is needed as partners of doctors. For hospital management, the important thing is not merely about who entered the prescription, but how the system is implemented to provide service for patients. Other factors affecting implementation of health information system are personal readiness, especially readiness to work paper-free in electronic system. Another factor is the senior manager's ability to place electronic prescribing system as the main priority, because without it, this system would not last long. Studies proved that lack of personal commitment and superior supports are among the obstacle of implementation of a new system (Maharani, 2009).

RSUD Meuraxa has implemented CPOE for more than two years and it would be impossible for this system to work without commitment from each personnel. The next step is how to maximize existing managerial function, starting from lower level management that is transaction processing system, middle 
level management that is management control system, and higher level management that is decision support system, so this information system would keep sustainable, and even be developed into a wider service form and follow information technology development according to need (Indrajit, 2009) so this CPOE development could improve service quality for patients (Kruse, 2015).

\section{Conclusion}

Our study found that effort expectancy positively influence behavioral intention in acceptance of electronic prescribing/ computerized physician order entry (CPOE), whereas facilitating conditions positively influence use behavior in acceptance of electronic prescribing/computerized physician order entry (CPOE) in RSUD Meuraxa, Banda Aceh City. It is expected that the management of RSUD Meuraxa, Banda Aceh city develops existing electronic prescription system by accommodating the need of system users, such as doctors, pharmacists, and patients into a more complex system in the hospital.

\section{References}

Aggelidis, Vassilios P, and Prodromos D Chatzoglou. 2008. Using a Modified Technology Acceptance Model in Hospitals. Int J Med Inform, 8: 115-26.

Appari, A., E. K. Carian, M. E. Johnson, and D. L. Anthony. 2012. Medication Administration Quality and Health Information Technology: A National Study of US Hospitals. Journal of the American Medical Informatics Association 19: 360-67.

Aqil, Anwer, Theo Lippeveld, and Dairiku Hozumi. 2009. PRISM Framework : A Paradigm Shift for Designing, Strengthening and Evaluating Routine Health Information Systems. Health Policy And Planning: 217-28.

Asyary, Al, Hari Kusnanto, and Anis Fuad. 2013. Sistem Peresapan Elektronik Pada Keselamatan Pengobatan Pasien Computerized Physician Order Entry on Patient Medication Safety. Jurnal Kesehatan Masyarakat UI 8(3): 125-32.

Benmessaoud, Christine, Hadi Kharrazi, and Karl F Macdorman. 2011. Facilitators and Barriers to Adopting Robotic-Assisted Surgery: Contextualizing the Unified Theory of Acceptance and Use of Technology. Plos One, $6(1)$.

Dhavle, AA, \& Rupp, MT. 2015. Towards creating the perfect electronic prescription. Journal of American Medical Informatics Association, $22: 12$.

Eslami, S, de Keizer NF, and Abu-Hanna AA. 2007. The Impact of Computerized Physician Medication Order Entry in Hospitalized Patients-A Systematic Review. International Journal of Medical Informatic, 77: 365-76.

Hahn, A, \& Lovett, A. 2014. Electronic Prescribing: An Examination of Cost Effectiveness, Clinician Adoption and Limitations. Universal Journal of Clinical Medicine, 2(1): 1-24.

Holden Richard J. 2010. Physicians' Beliefs About Using Emr And Cpoe: In Pursuit Of A Contextualized Understanding Of Health It Use Behavior. National Institute of Health 79(2): 1-16.

Hoonakker, P. L. T. et al. 2012. Changes in End-User Satisfaction with Computerized Provider Order Entry over Time among Nurses and Providers in Intensive Care Units. Journal of the American Medical Informatics Association, 20(2) : 252-59.

Hoonakker, Peter L T, Pascale Carayon, and James M Walker. 2010. Measurement of CPOE EndUser Satisfaction among ICU Physicians and Nurses. Applied Clinical Informatics, 1(3): 268-85.

Indrajit, Richardus Eko. 2009. Manajemen Sistem Informasi. Pengantar Konsep Dasar Manajemen sistem informasi dan teknologi informasi.

Kruse, Clemens Scot, and Kristina Goetz. 2015. Summary and Frequency of Barriers to Adoption of CPOE in the U.S. Journal of Medical Systems 39(2).

Maharani, Chatila. 2009. Sistem Manajemen Mutu ISO 9000 Sebagai Alat Pengikatan Kualitas Organiasasi Pelayanan Kesehatan. Jurnal Kesehatan Masyarakat Universitas Negeri Semarang 8(2): 113-20.

North, Frederick et al. 2014. Clinical Decision Support Improves Quality of Telephone Triage Documentation--an Analysis of Triage Documentation before and after Computerized Clinical Decision Support. $B M C$ Medical Informatics and Decision Making, 14(1): 20.

Raimbault-Chupin, et al. 2013. Drug related problems and pharmacist interventions in a geriatric unit employing electronic prescribing. International Journal of Clinical Pharmacy, 35(5): 847-53.

Phichitchaisopa, N \& Naenna, T. 2013. Factors Affecting the Adoption of Healthcare 
Information Technology. Experimental and Clinical Science Journal, 12: 413-436.

Poon, E. G. et al. 2004. Overcoming Barriers To Adopting And Implementing Computerized Physician Order Entry Systems In U.S. Hospitals. Health Affairs 23(4): 184-90.

Schreiber, R, K Peters, and S H Shaha. 2014. Computerized Provider Order Entry Reduces Length of Stay in a Community Hospital. Applied clinical informatics, 5: 685-98.
Tsai, Chung-Hung. 2014. Integrating Social Capital Theory, Social Cognitive Theory, and the Technology Acceptance Model to Explore a Behavioral Model of Telehealth Systems. International Journal of Environmental Research and Public Health, 11(5): 4905-25.

Vekantes, V, Morris, M, Davis G., Davis, G., Davis F. 2009. Tecnology Acceptance Model - Research :1-7. 